\title{
Challenging Employment Tribunal Fees: R (Unison) v Lord Chancellor and another (No.2)
}

In $R$ (Unison) $v$ Lord Chancellor and another (No.2) ${ }^{1}$ the High Court rejected Unison's second application for judicial review of the policy of charging claimants to the Employment Tribunal ("ET") and the Employment Appeal Tribunal ("EAT"). ${ }^{2}$ The policy, which was introduced across Great Britain by the coalition government in July 2013, removed the free access that has been in place since the National Industrial Relations Court was established by the Industrial Relations Act 1971. Had the court decided to strike it down, the judgment would have been effective in Scotland as well as in England and Wales. However, further devolution may lead to some interesting developments which are discussed at the end of this article.

\section{A. BACKGROUND}

The Fees Order and the Added Tribunals (Employment Tribunals and Employment Appeal Tribunal) Order $2013^{3}$ now determines that claims in the ET and appeals to the EAT can only be started and continued upon payment of fees ${ }^{4}$ unless an individual qualifies for a full or partial waiver known as a remission. ${ }^{5}$ Claims are divided into two types, each with two separate fees: Type A claims, which include unlawful deductions from wages and breach of contract, attract an issue fee of $£ 160$ and a hearing fee of $£ 230$; and Type B claims, which include unfair dismissal and discrimination, attract fees of $£ 250$ and $£ 950$. Different rates are applicable in claims involving multiple claimants. Appellants to the EAT are charged a lodgement fee of $£ 400$ and a hearing fee of $£ 1200$.

\footnotetext{
${ }^{1}$ [2014] EWHC 4198 (Admin), henceforth “R(Unison) No 2”.

2 Introduced by the Employment Tribunals and Employment Appeal Tribunal Fees Order 2013, SI 2013/1893.

${ }^{3}$ SI $2013 / 1892$.

${ }^{4}$ Art 3.

${ }^{5}$ In accordance with Art 17 and Sch 3 of the Fees Order.
} 
At a previous judicial review application ${ }^{6}$ Unison ran a number of arguments to challenge the legality of the regime. Although unsuccessful, not all of these arguments were completely rejected by the High Court with two (outlined below) found to lack the robust evidence required to justify overturning the policy. As the application had been brought prior to the publication of official statistics showing the decline in the number of ET claims, the court found that it was too early to say whether the fees would have the unlawful effects claimed by Unison, holding that "[i]t seems to us more satisfactory to wait and see and hold the Lord Chancellor to account should his optimism as to the fairness of this regime prove unfounded." "' Unison's appeal against this decision was subsequently stayed and permission was granted to bring a second application following the publication of official statistics.

\section{B. THE APPLICATION FOR JUDICIAL REVIEW}

In the fresh application Unison, with the Equality and Human Rights Commission as intervener, challenged the fees regime on two main grounds. Firstly, that it has had a negative effect on the access to justice of certain groups of claimants in violation of the EU principle of effectiveness, making it virtually impossible, or excessively difficult, for a significant number of potential claimants to afford to exercise rights conferred by EU law, thus making such rights illusory. Secondly, that the regime indirectly discriminates against women, who are more likely than other groups of workers to be on low incomes. The Lord Chancellor's failure to establish that such disadvantage is justified renders it unlawful under EU law, the ECHR, ${ }^{8}$ and section 19 of the Equality Act 2010.

In evidence Unison relied on statistical information which showed that from October to December 2013, following the introduction of fees, $79 \%$ fewer claims were accepted by the ET compared with the same quarter in the previous year. For equal pay claims the figure was $83 \%$ and for sex discrimination it was $77 \%{ }^{9}$ The statistics for January to March 2014 , which recorded a reduction of $81 \%$, showed that the earlier statistics were not aberrant.

\footnotetext{
${ }^{6} R$ (Unison) $v$ The Lord Chancellor and another [2014] EWHC 218 (Admin), heard by the High Court on 7 Feb 2014.

${ }^{7}$ Ibid, para 89.

${ }^{8}$ Art 6 read with Art 14.

${ }^{9}$ The Tribunals Statistics Quarterly for October to December 2013, published on 13 March 2014.
} 
The Lord Chancellor countered that the claims were still premature and that the generalised nature of the statistics relied upon and an absence of any examples of specific individuals who had been denied access to the ET made it impossible for the court to find in favour of the applicant. ${ }^{10}$

\section{THE JUDGMENT}

The court, comprised of Elias LJ and Foskett J with Elias LJ delivering the leading judgment, dismissed the application on both grounds. In considering the first ground, the court reviewed the relevant case law of the Court of Justice of the EU concerning the principle of effectiveness. Relying on the decisions in Impact $v$ Minister for Agriculture and Food ${ }^{11}$ and Alassini $v$ Telecom Italia $S P A,{ }^{12}$ the court found that any justifiable restrictions to the right of access to the courts must satisfy the proportionality test so that the imposition of unnecessary hurdles which hinder the exercise of the right will be enough to amount to a breach of the effectiveness principle. ${ }^{13}$

Unison's submission that the fees had contributed to the dramatic reduction in claims was rebutted by the Lord Chancellor who argued that other initiatives such as the ACAS early conciliation scheme, an increase in the qualifying period for unfair dismissal claims and the imposition of a lower cap on unfair dismissal compensation, had also had an impact. While the court agreed that these factors "may have played a part" but did "not begin to explain the whole of this very dramatic change", ${ }^{14}$ Unison's reliance on the statistical information was deemed to be inadequate: actual cases were required which would enable the court to review the income and expenditure of particular individuals so as to apply the effectiveness principle to a concrete situation: ${ }^{15}$

$<$ EXT $>$ The figures demonstrate incontrovertibly that the fees have had a marked effect on the willingness of workers to bring a claim but they do not prove that any of them are unable, as opposed to unwilling, to do so. $<$ EXT $>$

\footnotetext{
${ }^{10} R$ (Unison) No 2), para 5.

${ }^{11}$ Case C-68/06 [2008] ECR I-2483.

${ }^{12}$ Case C-317/08 [2010] ECR I-221.

${ }^{13}$ R(Unison) No 2), para 40.

${ }^{14}$ Para 57.

${ }^{15}$ Para 60.
} 
Turning to the allegation that the Type B fee has had a disproportionate impact on discrimination claimants, most of whom are women, the court held that it was not appropriate to argue indirect discrimination based on a self-selected sub-group (i.e. the number of women bringing discrimination claims as a proportion of all claimants) because if a different subgroup were selected, the reverse could be true. The statistics on unfair dismissal cases, for example, demonstrated an adverse impact on men. ${ }^{16}$ The central question was not whether any fee was justified but whether the different fee rates for Types A and B claims were justified. Accordingly, the rationale for the different rates, which was that the more complex Type B cases required a higher allocation of court resources, was legitimate. ${ }^{17}$

In response to Unison's submission that cost-saving was the sole or principal aim of the fees regime, the court found that the government had actually identified three objectives: to transfer one-third of the annual running costs to users; to make tribunals more efficient and effective not least by removing unmeritorious claims; and to encourage alternative methods of employment dispute resolution other than litigation. ${ }^{18}$ The court found each of these objectives to be legitimate. If viewed in its wider context, including the possibility of remission for those on low incomes and the recoverability of the costs for successful claims, any discrimination arising was found to be justified and proportionate.

Permission to appeal to the Court of Appeal was granted.

\section{COMMENT}

Unison has announced its intention to appeal. ${ }^{19}$ In keeping with the judgment, such an appeal will require evidence relating to specific individuals who were prevented from pursuing viable claims on affordability grounds. This might be easier said than done. The dramatic decline in claims is likely to be reflected in a fall in the number of individuals seeking advice and support through the usual channels, thus making it difficult to identify a pool of potential claimants. Of course, there will be some who found out about the imposition of fees only on seeking advice and who were refused remission. However, to require such individuals to

\footnotetext{
${ }^{16}$ Para 71.

${ }^{17}$ Para 69.

${ }^{18}$ Para 83.

${ }^{19}$ See http://www.unison.org.uk/unison-to-appeal-high-court-decision-over-tribunal-fees.
} 
participate in litigation which is not directly concerned with resolving their personal dispute is a lot to ask. Even where willing individuals are forthcoming, the standard against which their circumstances will be judged is likely to prove rather difficult to meet: ${ }^{20}$

$<$ EXT $>$ The question many potential claimants have to ask themselves is how to prioritise their spending: what priority should they give to paying the fees in a possible legal claim as against many competing and pressing demands on their finances? And at what point can the court say that there is in substance no choice at all? $<$ EXT $>$

Such individuals will have to be outside of the eligibility requirements for remission, for which qualification depends on receipt of a means-tested benefit, and yet still be able to demonstrate that the fees are unaffordable. It is not uncommon for an individual's finances to be in a state of flux following an employment dispute. This may be as a result of the dispute itself. The transition to a new job, perhaps requiring an application for in-work benefits, can make it difficult to establish a financial snapshot on which to base a rational decision about whether to lodge an ET claim, never mind one which is capable of satisfying the conditions set out by the High Court.

The financial outlay is only one of a much wider range of costs incurred by individuals caught up in employment disputes. Other human costs include the effects on the individual's health and wellbeing and that of his or her family. ${ }^{21}$ How much account the court will take of relevant life circumstances is unclear yet such backstories may be critical in influencing decision-making for those who find themselves in financial straits, particularly in the current economic climate. ${ }^{22}$

Any assessment of individual decision-making, therefore, requires consideration of the bigger picture in which wider contextual factors combine to make the fees the last in a long line of barriers to justice. In its submission Unison outlined a range of such factors which, even in the pre-fees era, militated against claimants ${ }^{23}$ including the lack of affordable legal representation and feelings of intimidation at the prospect of self-representation; the low

\footnotetext{
${ }^{20}$ R(Unison) No 2), para 61.

${ }^{21}$ See N Busby and M McDermont, "Workers, marginalised voices and the employment tribunal system: some preliminary findings" (2012) 41 Industrial Law Journal 166.

${ }^{22}$ For examples of individual stories see the case studies from the ongoing project "Citizens Advice Bureaux and Employment Disputes" available at http://www.bristol.ac.uk/law/research/centres-themes/aanslc/cabproject/employmenttribunalfees/.

${ }^{23}$ R(Unison) No 2), para 47.
} 
rates or absence of compensation in some claims; and the difficulties experienced by many successful claimants in enforcing a money judgment. ${ }^{24}$ When placed in this context, spending $£ 390$ to chase a similar amount in unpaid wages is probably not a risk worth taking.

However, if a claimant in this position were found to have access to $£ 390$, could it still be asserted that the fee had made access to justice "excessively difficult"?

Recognition of the near impossible task that the High Court has set for Unison brings us back to the ET statistics which, on a closer reading of the judgment, actually appear to have been very persuasive in convincing the court that fees have made it excessively difficult for many claimants to proceed. In Elias LJ 's statement that the statistics "...demonstrate incontrovertibly that the fees have had a marked effect on the willingness of workers to bring a claim", ${ }^{25}$ it is the use of the term "willingness" rather than "ability" that introduces the margin of doubt exploited in the judgment. Perhaps Lord Foskett's words provide a stronger endorsement of Unison's approach: ${ }^{26}$

$<$ EXT $>$ The effect of the new regime has been dramatic ... so dramatic that the intuitive response is that many workers with legitimate matters to raise before an ET must now be deterred from doing so because of the fees that will be demanded of them before any such claim can be advanced. $<$ EXT $>$

It is unfortunate that the court felt unable to make the inference required to find the statistics capable of demonstrating that the fees represent a substantial and insurmountable barrier to justice for many workers.

\section{E. THE FUTURE: A NORTH-SOUTH DIVIDE?}

The fees policy is likely to provoke much further debate and may even prove to be the catalyst for a divergence in approach between Scotland and England and Wales. The Scottish

\footnotetext{
${ }^{24}$ The government's own research has revealed that only $49 \%$ of successful claimants were paid in full and a further $16 \%$ were paid in part, the Department for Business, Innovation and Skills (2013) "Payment of Tribunal Awards", available at https://www.gov.uk/government/uploads/system/uploads/attachment_data/file/253558/bis-131270-enforcement-of-tribunal-awards.pdf.

${ }^{25} R$ (Unison) No 2), para 60.

${ }^{26}$ Para 96.
} 
judicial review in which law firm Fox and Partners has petitioned the Court of $\operatorname{Session}^{27}$ was sisted pending the outcome of Unison's application and may now go ahead. Even without further litigation the fees are likely to feature in political agendas on both sides of the border in the lead-up to the general election. The Smith Commission Report ${ }^{28}$ proposed further devolution of the tribunal system with the transfer of the management and operation of the ET to the Scottish government, which has long been opposed to fees. Unless safeguards are put in place, any change to policy in Scotland, such as the abolition of fees, could presumably lead to jurisdiction shopping with employment claims which arise south of the border being brought before the Scottish ET. Furthermore, the Labour Party has indicated that, if elected in 2015, it plans to reform the ET system with a review of fees likely to form a central plank of those reforms. Rather than the final act, the current case appears to be the latest scene in a long-running drama. It is hoped that those workers whose access to justice has been denied are not merely consigned to supporting roles.

Nicole Busby

University of Strathclyde

${ }^{27}$ [2013] CSOH 133.

${ }^{28}$ Report of the Smith Commission for further devolution of powers to the Scottish Parliament (2014), para 63. 